\title{
MORPHOLOGY CHANGE CAUSED BY THE 2011 GREAT TOHOKU TSUNAMI WAVE - MECHANISM OF RECENT CLOSURE AND BREACHING OF THE NANAKITA RIVER MOUTH
}

\author{
Nguyen Xuan Tinh ${ }^{1}$, Hitoshi Tanaka², Ryutaro Hirao ${ }^{3}$, Eko Pradjokoº, Akira Mano ${ }^{5}$ and \\ Keiko Udo ${ }^{6}$
}

\begin{abstract}
The 2011 Great Tohoku Earthquake and Tsunami in March had caused a lot of damages to people and infrastructure in Japan. With a giant tsunami height plus the subsidence due to earthquakes have destroyed most of the nearshore constructions and coastal zone areas. According to measured data from the survey group (Mori et al. 2011); maximum tsunami wave height measured at the Nanakita area is about $14 \mathrm{~m}$. This Tsunami made the topography of this region changed drastically. Many breaching places occurred along the coast and river mouth. This study will focus on investigating the mechanisms of sediment transport and hydrodynamics leading to the river mouth was closed in about five months after the event and then breached in a different location during the river flood.
\end{abstract}

Keywords: Nanakita River, Tohoku Tsunami, Great Tohoku Earthquake, Morphology Change, Erosion, Breaching

\section{INTRODUCTION}

Tsunami is usually caused by an earthquake. As the tsunami wave approaches near to the shoreline it can cause an extreme damage to the coastal zone as well as people due to huge wave energy dissipation at shallower water depth. The tsunami wave can also further penetrate into the upstream of rivers; the water level rise due to tsunami impact can be very significant high. Inundation area and wave overtopping the river embankments could be observed. Therefore, tsunami impacts to river upstream studies become more important. The main objectives of this study are to investigate the tsunami wave impacts to river morphologies based on real time measurements during the 2010 Chilean Tsunami and 2011 Tohoku Tsunami events.

There are many researches on the impacts of the tsunami on the coastal zone topography evolution either in a short-term or long-term of morphological changes such as Takahashi et al. , 2000., Nanayama et al. , 2000., Chavanich et al. , 2005., Tanaka et al. , 2007., Matsumoto et al. , 2008., Choowong et al. , 2009., Pari et al. , 2008., and Goto et al. , 2011.. Most of studies are based on the analysis of morphological changes data from the 2004 Indian Ocean Tsunami. Among them, Pari et al. , 2007 and Goto et al. , 2011. indicated that the tsunami transformed the remarkable sea bottom topography especially in the wave breaking region. Not all of the sediment from the eroded part was transported to the landward, but also deposited in the sea. The changes of coastal area are caused not only by the incident tsunami waves but also by the tsunami return flow. In general, the return current flows into the low-elevated areas or into the river channels and dramatically changes morphology. Dependent on the local hydrodynamic regimes and sediment transport mechanisms, restoration of coast is quick or slow. In some locations, this recovering process takes only a few months or years, but other locations are difficultly recovered to its original conditions (Tanaka et al., 2012).

The 2011 Great Tohoku Earthquake and Tsunami in March had caused a lot of damages to people and infrastructure in Japan. With a giant tsunami height plus the subsidence due to earthquakes have destroyed most of the nearshore construction and coastal zone including Sendai Coast. According to data measured by the survey group (Mori et al. 2011); maximum tsunami height measured at the Nanakita area is about $14 \mathrm{~m}$. This Tsunami made the topography of this region changed drastically. Many breaching places occurred along the coast and river mouth. This study will focus on investigating the mechanisms of sediment transport and hydrodynamics leading to the river mouth was closed five months after the tsunami and broken in a different location during the river flood. The analyzed results have been shown that the tsunami wave can be affected up to several tens kilometer upstream of a large river and the measured tsunami travel time inside the river is almost similar to the tsunami travel time

\footnotetext{
${ }^{1}$ Post-doctor Fellow, Department of Civil Engineering, Tohoku University, 6-6-06 Aoba, Sendai 980-8579, Japan

${ }^{2}$ Professor, Department of Civil Engineering, Tohoku University, 6-6-06 Aoba, Sendai 980-8579, Japan

${ }^{3}$ Graduate Student, Department of Civil Engineering, Tohoku University, 6-6-06 Aoba, Sendai 980-8579, Japan

${ }^{4}$ Graduate Student, Department of Civil Engineering, Tohoku University, 6-6-06 Aoba, Sendai 980-8579, Japan

${ }^{5}$ Professor, Department of Civil Engineering, Tohoku University, 6-6-06 Aoba, Sendai 980-8579, Japan

${ }^{6}$ Assoc. Professor, Department of Civil Engineering, Tohoku University, 6-6-06 Aoba, Sendai 980-8579, Japan
} 
calculated by using the long wave theory. The restoration process of the breaching locations along the coast and estuaries is much dependent on the hydrodynamic regimes and sediment supply availability in that area. Depending on these two factors, the recovery process to reach original form of the beach can be fast or slow. These outcome results can provide a good idea for river and coastal countermeasure designs against future tsunami events.

\section{DATA COLLECTION AND ANALYSIS}

The study area concentrates on the coasts and rivers in the Sendai Coast, located in the eastern part of Miyagi Prefecture in Japan as shown in Fig.1. This sandy beach is limited by the Nanakita River mouth in the south and Sendai Port in the north. The Nanakita River is belonged to the Class B River in Japan which is managed by the prefectural government and relatively smaller river catchment than those rivers managed by the national government. In order to achieve the objectives, an attempt is made to collect as many required data sets as possible. The data are included the aerial photographs and wave information data.

The aerial photographs were taken frequently and immediately after the tsunami disaster by the Geographical Survey Institute (hereinafter referred to as GSI for citation), the Kitakami River Lower Reach Office, the Ministry of Land, Infrastructure and Transport (MLIT) and by ourselves. Based on these data, a quantitative analysis of morphology changes can be attained. These complied data sets enable us to examine the coastal morphological responses such as sediment erosion or deposition due to the 2011 tsunami and also to investigate the coastal and river morphology recovering processes after about eleven months since the 2011 tsunami. In this study, the shoreline position detected in the aerial photographs was corrected to define it in terms of the mean sea level, considering the tidal level at aerial photo shooting as has been done by Pradjoko and Tanaka, 2011. for the northern part of the Sendai Coast.

Besides beach erosion induced by the tsunami, another cause of shoreline retreat is land subsidence, ranging from $40 \mathrm{~cm}$ to $80 \mathrm{~cm}$ in the study area according to Geospatial Information Authority of Japan , 2012.. Although this effect induced by subsidence is not eliminated from measured shoreline retreat, it can be roughly estimated to be around $4 \mathrm{~m}$ to $8 \mathrm{~m}$ using the averaged beach slope reported by Pradjoko and Tanaka, 2011.

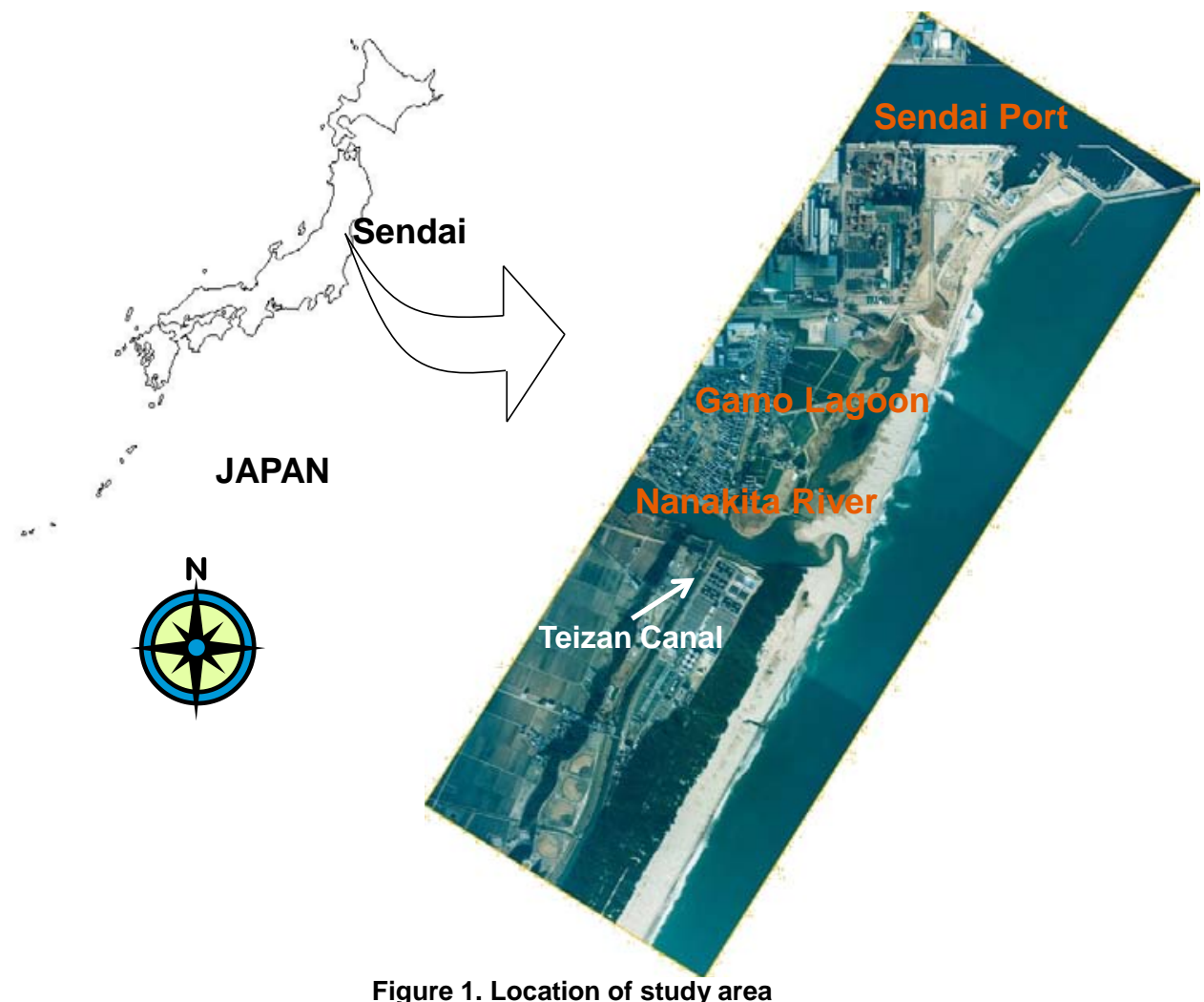

Figure 1. Location of study area 


\section{Wave information}

In corresponding to the coastal recovery processes, the time series of wave information such as wave height, wave period and wave direction are required. The data was collected from the Sendai wave station and shown in Fig. 2. Note that there were missing data in March due to the station was destroyed by either tsunami waves or electricity lost.

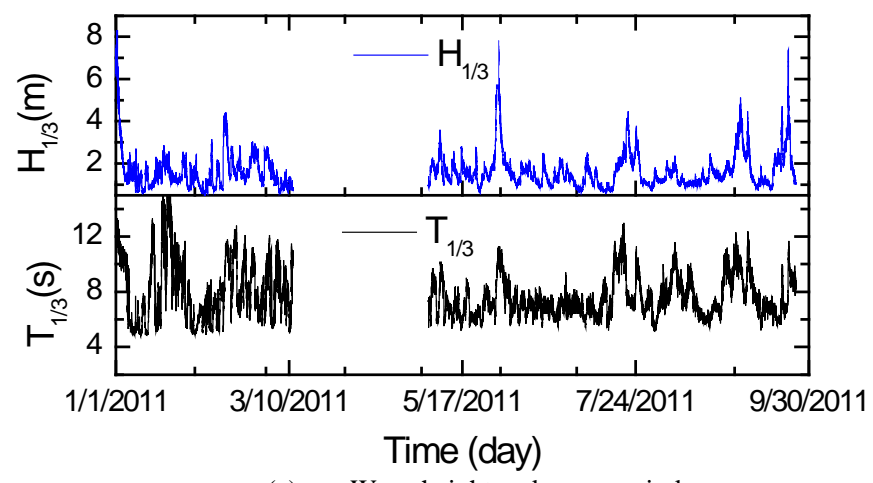

(a) - Wave height and wave period

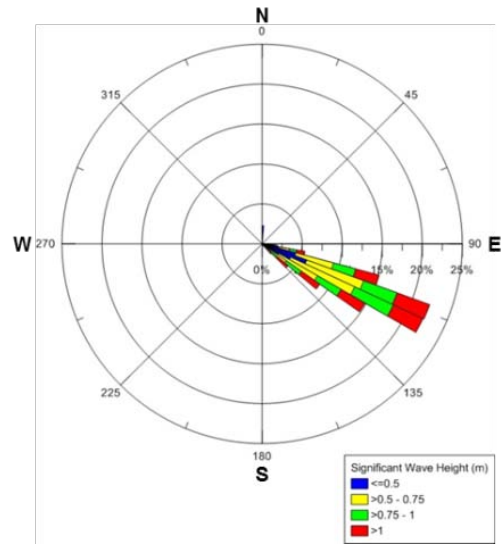

(b) Wave direction

Figure 2. Wave information obtained from Central Miyagi Buoy station

\section{RESULTS AND DISCUSSION}

In this section, the morphology changes of Nanakita area before, during and after the 2011 Tohoku Tsunami event will be discussed separately.

\section{Before the 2011 Tohoku Tsunami Event}

The study area is divided into three different areas based on its morphological characteristics (Fig. 3). The Area 1 is limited by the breakwater structure of Sendai Port and bounded by a $10 \mathrm{~m}$ height of man-made embankment. The backshore of Area 2 is Gamo Lagoon and initial dune elevation about 3 $\mathrm{m}$. The Area 3 is bordered by pine tree forest.

Based on the analysis of the past 60 years measured shoreline positions, Pradjoko et al. (2011) have been shown that the long-term morphological changes around the Nanakita River mouth area had great impacted by the construction of Sendai Port breakwater since 1970, as shown in Fig. 3 on below section-plots. The Area 1 was eroded and became curve shoreline. The Area 2 and 3 were accreted after the construction of Sendai Port breakwater. Recently, the shoreline around Nanakita River mouth just fluctuates to respond the seasonal variation of wave and river discharge in the last 5 years. The calm waves build the beach and the shoreline become advance during winter and spring season in January until May. The big waves and typhoons eroded the beach which made the shoreline retreat during summer and autumn season in June until November. The high river discharge also occurs in this period and supply sediment in front of river mouth. In general, the shoreline around Nanakita River mouth is reached to the dynamic equilibrium stage before the 2011 Tsunami. 

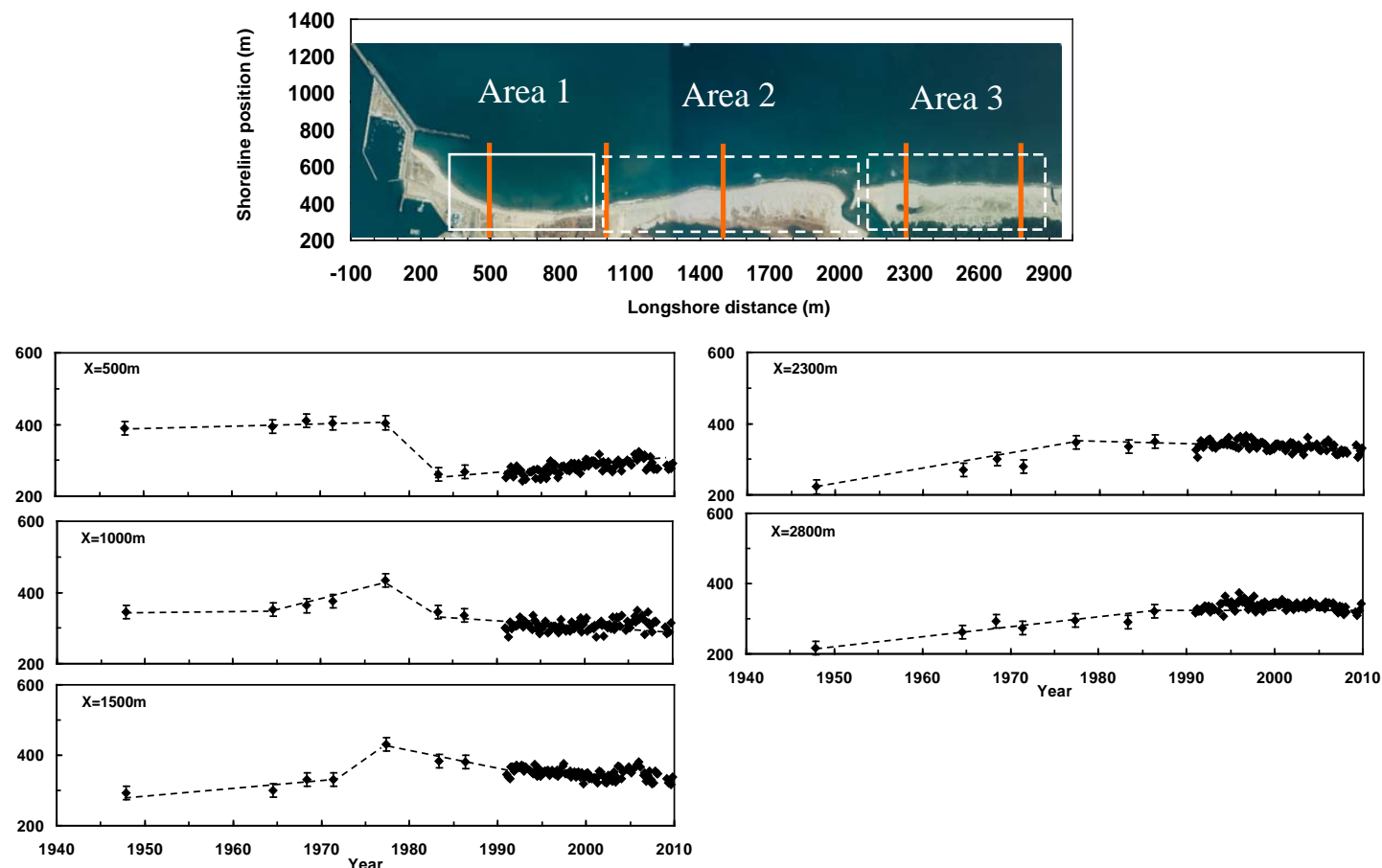

Figure 3. The shoreline position at some section around river mouth about 60 years before tsunami

\section{After the 2011 Tohoku Tsunami Event}

According to data measured by the survey group (Mori et al. 2011); maximum tsunami height measured at the Nanakita area is about $14 \mathrm{~m}$. Fig. 4 shows the series of aerial photographs taken at different time in Sendai Coast. The first photo was taken just five days before the tsunami. The second photo was taken just two days after the tsunami and the comparison shown a huge morphologically changes in this area. A sand spit at the Nanakita River mouth has completely disappeared. There several locations were breached along the coast and elevation of the coast has declined significantly. The photos also suggest that most sediment transported and deposited in the Gamo Lagoon on behind sand dune, a part of sediment moving out to sea by the tsunami return flow. The river water depth and width are also become deeper and wider (Fig. 2b).
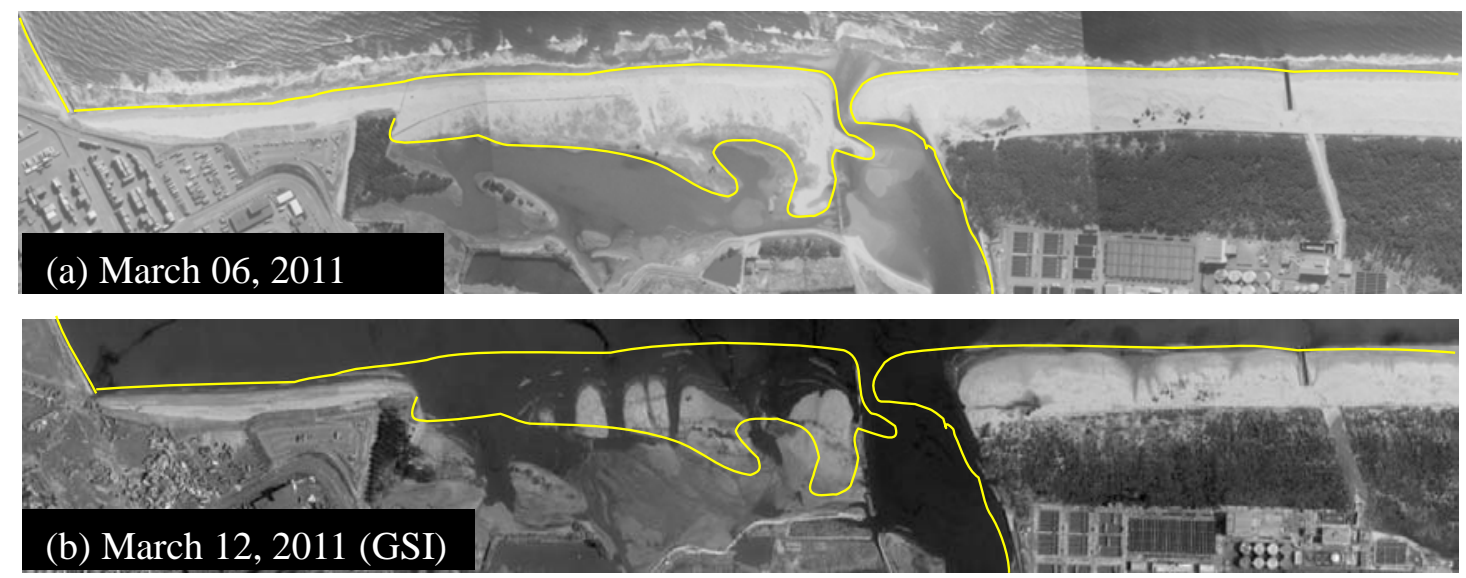

Figure 4. Nanakita Area morphology change before and after the 2011 Tsunami (after Tanaka et al., 2012)

\section{Mechanisms of River mouth Closure}

A comprehensive investigation of river mouth topography change has already been carried out by Tanaka and Shuto (1992), Tanaka et al. (1996), Tanaka and Ito (1996), and Tinh and Tanaka (2011). 
The water depth at the mouth is around $1.5 \mathrm{~m}$ and thus most of the waves tend to break near the entrance of the river mouth. Due to its small catchment area, the river discharge is usually very little, especially during winter. The complete closure of the Nanakita River mouth was observed in 1988 and 1993 (Tanaka et al. 1996).

As mentioned, this area is quite in stable condition before the earthquake and tsunami event in 2011. However, because of the topographical changes caused by tsunami waves made hydrodynamics and sediment transport mechanisms are also changes. According to Kang and Tanaka (2005), the direction of longshore sediment transport along the coast in this area is from south to north, so the sand will be moved from the south river bank of the Nanakita River to the north caused by wave-induced current. The morphology variation at the Nanakita estuary area before and after the tsunami is shown in Fig. 5. Under the influence of the tsunami, the sand dune on the right hand side of the river mouth was eroded greatly; the new shoreline moved to landward as illustrated in Fig. 5. Sand dunes were completely destroyed and sand spit at the mouth of the river was moved away. The width at the mouth became large compared to the original one (Fig. 5). Although there is no available field data for the river mouth depth, it might have distinctly increased due to severe erosion judging from the observation at the Natori River mouth (Tanaka et al., 2012).

Figures 5(a), 5(b) and 5(c) are aerial photographs taken after about three, four and six months after the tsunami event, respectively. All breached portions due to the tsunami have been connected again after three months as seen in Area 2 in Fig. 5(a). There was a new sand spit formed at further inside of the river after three months, and subsequently a second sand spit was formed a month later (Fig. 5(b)). At the beginning of August, the river entrance was observed to be completely closed (Fig. 5(c)). There are several different natural mechanisms related to the formation of sand spit in the river and complete closure as follows. The first reason is because of longshore sediment transport from the south to the north, so that the area of sandy beach in Area 3 (Fig. 5(b)) was gradually reduced and the eroded sediment was transported to the river mouth area. In addition, the left end of the sandy coast, Area 1, was also eroded in Fig. 5(c) and the central portion of the coast was filled with sand. The second reason is due to the significant increase of water depth and width of river mouth allowed waves to intrude further inside of the river, resulting in sand spit formation further upstream. The third reason is because of the impact of tsunami waves destroyed a lock gate at the location of Teizan Canal (Fig. 1). Without this gate, the flow is always from the Nanakita River to the Natori River due to water level rise in the Nanakita River mouth induced by wave set-up (Tanaka and Shuto, 1992). The river mouth might not have been closed if the river discharge is maintained by closing the lock gate. However, because the lock gate was destroyed, some amount of river discharge flows into this canal to the Natori River and reduced the discharge through the Nanakita River mouth. Finally, the river mouth was closed seen in Fig. 5(c). This closure phenomenon is quite similar to what was observed by Tanaka et al. (1996). 

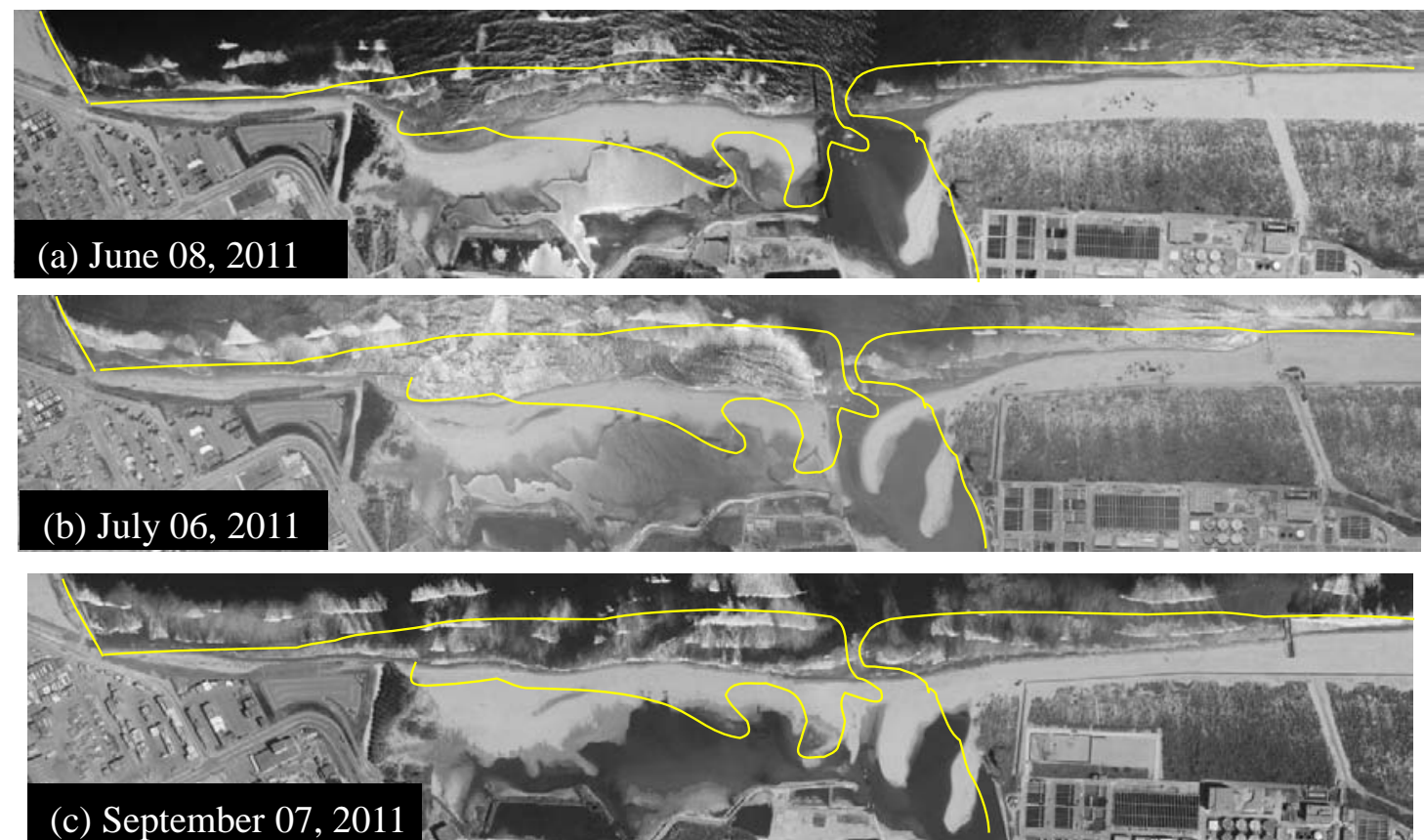

Figure 5. Morphological changes after the 2011 Tohoku Tsunami (after Tanaka et al., 2012)

\section{Breaching on the Gamo Lagoon Area and Recovering Processes}

Figure 6 is a continuous aerial photograph from Fig. 5 above and showing the new breaching location and recovery process of coastal morphology until February 13, 2012. From September 19 to 22, 2011, a severe typhoon, called Roke Typhoon attacked Japan. The typhoon caused widespread rainfall for a few days in Tohoku District. Due to this typhoon, a big river flooding occurred in the Nanakita River on September 21. Because of the river mouth closure at that time, the water level rose up and overflew to the lowland area. Finally, breaching occurred on the beach at the Gamo Lagoon area in September 21, 2011 as shown in Fig. 7.

In next following months until February 2012, the shoreline recovery was mainly by the long-shore transport processes see Figures 6(c), 6(d), 6(e), 6(f). Figure 7 shows the shoreline position analysis at the same sections as before the tsunami section. The breaching part (Area 2) acted as a sink and was filled by sand movement from nearby areas such as Area 1 and Area 3. On the other hand, the recovery of Area 2 is taking sediment from the Area 1 and Area 3, it is therefore the Area 2 tends to advance and other 2 nearby areas tend to retreat after almost a year of the 2011 Tsunami event (Fig. 7). However, the source of sediment from the south is limited due to the blockage of water outlet structure on the right side. The future recovery of coastal morphology around the Nanakita River mouth will only depend on sediment supply from the river itself if there is no artificial sediment bypassing activity in the water outlet structure.

Recovering processes in sand dune at the Gamo lagoon area are not only due to the longshore sediment transport but also cross-shore sediment transport by storms. Tinh and Tanaka (2011) have shown that approximately $1000 \mathrm{~m}^{3}$ of deposited sand on the beach surface by overwashing waves during a storm attacked this region in 2010; the maximum offshore wave height was around $4 \mathrm{~m}$. Fig. 2 shows there were four different events which has offshore wave height higher than $4 \mathrm{~m}$ after the March 11. Therefore, the cross-shore sediment transport is very significant during this recovering period. 

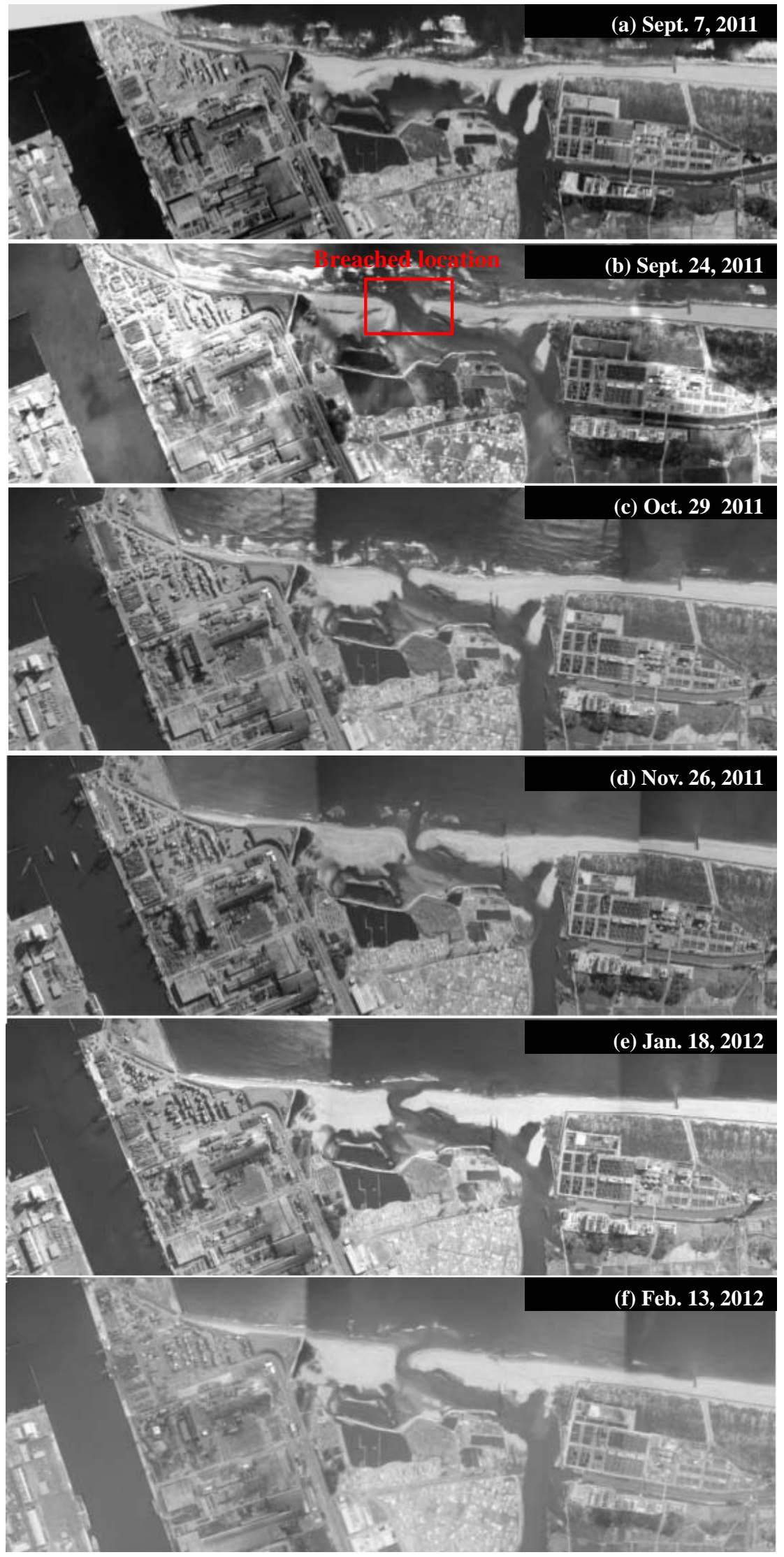

Figure 6. Breaching and recovery of morphology around Nanakita River mouth until February 2012 

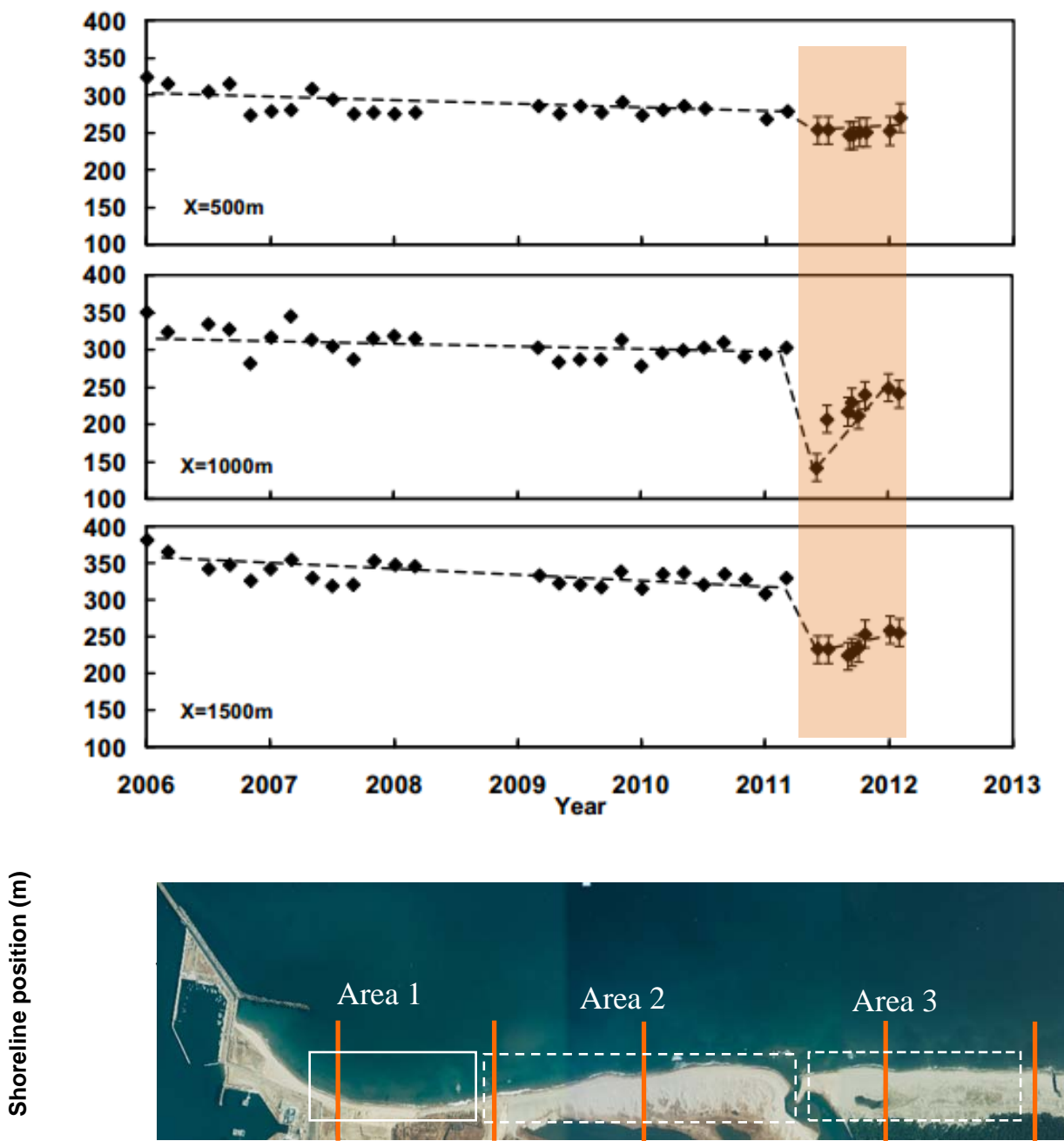

Longshore distance $(\mathrm{m})$

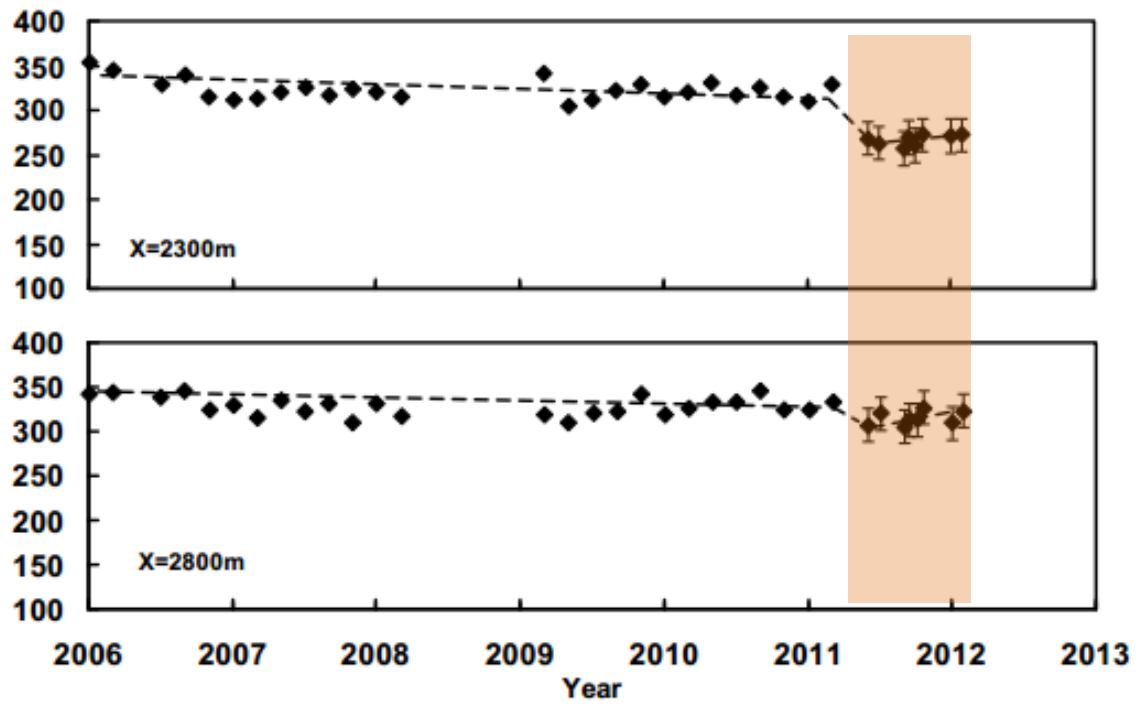

Figure 7. The shoreline position at some section around river mouth after the 2011 Tsunami 


\section{Excavating the previous river mouth location}

Keeping the new breached opening of river mouth in this area might cause some problems with the future river flooding events since it is probably blocked water flow to the sea and caused local inundation. In addition, maintaining of the Gamo Lagoon environment is important for the migrating birds in this area. Because of that the local government had excavated the previous river mouth location by constructed a new jetty on the leftside of river mouth and closed the Teizan Canal to maintain the opening of river mouth as shown in Fig. 8.

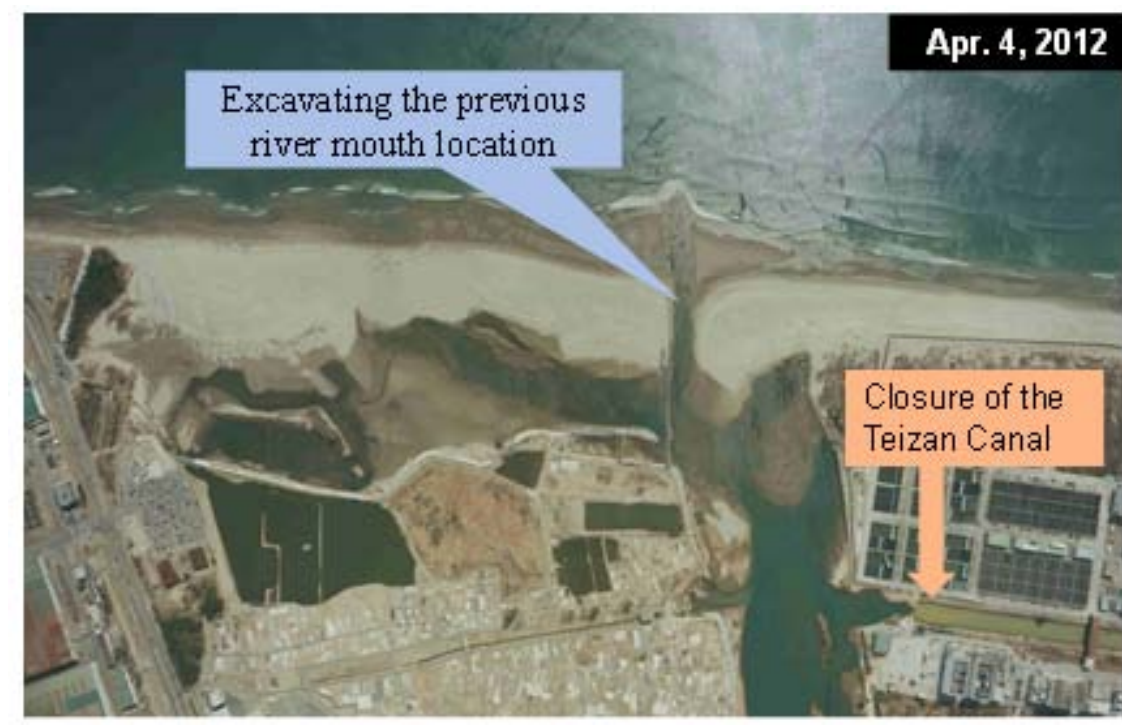

Figure 8. Latest aerial photograph shows the new excavated river month at the same previous river location

\section{CONCLUTIONS}

The impacts of the 2011 Earthquake and Tsunami on the Nanakita Area are presented in this study. The mechanisms of river mouth closure and breaching as well as the recovering processes of this area after the tsunami are figured out. A combination of several processes such as long-shore and crossshore sediment transports is the main factors to recover. Nevertheless, the restoration process of the breaching locations is much dependent on the hydrodynamic regimes and sediment supply availability in that area. Depending on these two factors, the recovery process to reach original form of the beach can be fast or slow. The Nanakita River mouth is a typical example of fast morphology recovery due to sufficient sediment supply from the surrounding area.

\section{ACKNOWLEDGMENTS}

The authors wish to express grateful thanks to the Kitakami River Lower Reach Office, the Ministry of Land, Infrastructure and Transport as well as Sendai Office of River and National Highway, Ministry of Land Infrastructure and Transport for providing us aerial photographs and other data sets. Their appreciation should be extended to the Miyagi Prefectural Museum for their permission to use the old map in the present paper. This research could not be conducted without the financial supports from the Grant-in-Aid for Scientific Research from JSPS (No. 21-360230, No. 22360193), Grant-in-Aid for Scientific Research from the River Environmental Fund (REF) in charge of the Foundation of River and Watershed Environmental Management (FOREM), and the Collaborative Research Fund, Disaster Prevention Research Institute, Kyoto University, as well as Assistance for Technological Development, Tohoku Construction Association. The authors would like to gratefully appreciate their supports.

\section{REFERENCES}

Chavanich, S., Siripong, A., Sojisuporn, P. \& Menasveta, P. , 2005. "Impact of tsunami on the sefloor and corals in Thailand," Coral Reefs 24, 535.

Choowong, M., Phantuwongraj, S., Charoentitirat, T., Chutakositkano, B., Yumuang, S. \& Charusiri, P. , 2009. "Beach recovery after 2004 Indian Ocean tsunami from Phang-nga Thailand," Geomorphology 104, 134-142. 
Geospatial Information Authority of Japan , 2012. "Land subsidence caused by the 2011 Tohoku Earthquake and Tsunami,” http://www.gsi.go.jp/common/000059956.pdf. (in Japanese)

Goto, K., Takahashi, J., Oie, T. \& Imamura, F. , 2011. "Remarkable bathymetric change in the nearshore zone by the 2004 Indian Ocean tsunami: Kirinda Harbor, Sri Lanka,” Geomorphology 127, 107-116.

Kang, H.W. \& Tanaka, H. [2006] “Influence of cross-shore sediment movement on long-term shoreline change simulation," Proc. 4th Int. Conf. on River, Coastal and Estuarine Morphodynamics, pp.343-348, 2005.

Matsumoto, D., Naruse, H., Fujino, S., Suphawajruksaku, A., Jarupongsaku, T. \& Sakakura, N. , 2008. "Truncated frame structures within deposit of the Indian Ocean Tsunami: evidence of synsedimentary deformation,” Sedimentology 55, 1559-1570.

Mori, N., Takahashi, T., Yasuda, T. \& Yanagisawa, H. , 2011. "Survey of 2011 Tohoku earthquake tsunami inundation and run-up,” Geophysical Research Letters 38 doi:10.1029/2011GL049210.

Nanayama, F., Sigeno, K., Satake, K., Shimokawa, K., Koitabashi, S., Miyasaka, S. \& Ishii, M., , 2000. "Sedimentary differences between the 1993 Hokkaido - Nansei-oki tsunami and the 1959 Miyakojima typhoon at Taisei, southwestern Hokkaido, northern Japan,” Sedimentary Geology 135, 255-264.

Pari, Y., Ramana Murthy, M.V., Jaya kumar, S., Subramanian, B.R. \& Ramachandran, S., , 2008. "Morphological changes at Vellar estuary, India e impact of the December 2004 tsunami,” Journal of Environmental Management 89, 45-57.

Pradjoko, E. \& Tanaka, H. , 2011. “Aerial photograph of Sendai Coast for shoreline behavior analysis” Proc. 32nd Int. Conf. on Coastal Engineering. P.13.

Takahashi, T., Shuto, N., Imamura, F. \& Asai, D. , 2000. "Modeling sediment transport due to tsunamis with exchange rate between bed load layer and suspended load layer," Proc. 27th Int. Conf. on Coastal Engineering, pp.1508-1519.

Tanaka H., Tinh N.X., Umeda M., Hirao R., Pradjoko E., Mano A., Udo K., 2012. “Coastal and estuarine morphology changes induced by the 2011 Great East Japan Earthquake Tsunami,” Coastal Engineering Journal, 54 (2012) http://dx.doi.org/10.1142/S0578563412500106 (25 pp)

Tanaka, H. \& Ito, T. , 1996. "An estimation method of gorge section at a small river mouth,” Coastal Engineering in Japan 39(1), 27-38.

Tanaka, H. \& Shuto, N. , 1992. "Field investigation at a mouth of small river," Proc. 23rd Int. Conf. on Coastal Engineering, pp. 2486-2499.

Tanaka, H., Ishino, K., Nawarathna, B., Nakagawa, H. \& Yano, S. , 2007. “Coastal and river mouth morphology change in Sri Lanka due to 2004 Indian Ocean Tsunami,” Proc. Coastal Sediments '07, pp.842-855.

Tanaka, H., Takahashi, A. \& Takahashi, F. , 1996. "Complete closure at the Nanakita River mouth in 1995,” Proc. 25th Int. Conf. on Coastal Engineering, pp.4545-4556.

Tinh, N.X. \& Tanaka, H. , 2011. "Discussion of overwash prevention construction on the northern part of Sendai Coast,” Proc. 6th Int. Conf. on Coastal Structures. (CD-ROM) 